Indonesian Journal of Legality of Law
e-ISSN : 2477-197X
https://postgraduate.universitasbosowa.ac.id/

\title{
ANALISIS YURIDIS PENEGAKAN HAK AZASI MANUSIA TERHADAP PENJATUHAN PIDANA PENCABUTAN HAK POLITIK TERPIDANA KORUPSI
}

\section{Juridical Analysis Of Human Rights Enforcement On The Implementation Of The Political Rights Revocation Of Corruptors}

\author{
Muhtar Syarief ${ }^{1}$, Marwan Mas ${ }^{2}$, Abd. Salam Siku² \\ ${ }^{1}$ Pengadilan Tinggi Kota Palu \\ ${ }^{2}$ Program Studi Ilmu Hukum Program Pascasarjana Universitas Bosowa \\ Email: muhtar@gmail.com
}

Diterima: 10 September 2021/Disetujui: 21 Desember 2021

\begin{abstract}
ABSTRAK
Penelitian ini bertujuan menganalisis terdakwa siapa saja yang terlibat dalam perkara korupsi yang berhak dijatuhi pidana tambahan. Jenis penelitian yuridis normatif. Sumber data sekunder. Bahan hukum primer putusan hakim. Analisis data pada penelitian hukum yuridis normatif ini secara deskriptif kualitatif. Hasil penelitian diperoleh menunjukkan bahwa penjatuhan putusan pidana tambahan berupa pencabutan hak memilih dan dipilih dalam jabatan publik kepada terpidana korupsi merupakan upaya yang menjerakan bagi para terpidana korupsi serta upaya preventif terjadinya tindak pidana korupsi, akhirnya penulis merekomendasikan untuk agar hakim harus konsisten dalam menjatuhkan pidana tambahan pencabutan hak politik serta mencantumkan kapan mulai berlakunya serta batas waktu berlakunya.
\end{abstract}

Kata Kunci: Pencabutan Hak Politik, Terpidana Korupsi, HAM

\begin{abstract}
This study aims to analyze the defendants who were involved in a corruption case who have the right to be sentenced to additional crimes. This study is normative juridical research. Secondary data sources were primary legal materials for the judge's decision. Data analysis in this normative juridical legal research is descriptive qualitative. The results obtained show that the imposition of additional criminal decisions in the form of revocation of the right to vote and to be elected in public office to corruptors is an effort to deter corruptors as well as efforts to prevent corruption. Finally the author recommends that judges must be consistent in imposing additional crimes of political rights revocation and stating when it comes into effect and the time limit for this.
\end{abstract}

Keywords: Political Rights, Corruptors, Human Right

(c) ()

\section{PENDAHULUAN}

Negara Indonesia merupakan suatu negara yang berlandaskan pada hukum dengan sistem demokratis dan didasarkan pada Pancasila serta Undang-Undang Dasar 1945, yang dimana dalam aturan tersebut memuat ketentuan bahwa setiap warga negara berkewajiban untuk menjunjung tinggi HAM serta menjamin segala sesuatu terhadap warga negara yang bersamaan dengan kedudukan di mata hukum serta di mata pemerintahan yang diwajibkan menjunjung tinggi hukum dan pemerintahan itu tanpa ada kecualinya (Atmasasmita, 2016). Namun dalam kondisi realnya, terkadang hukum tersebt diperhadapkan pada situasi yang serba salah. Seperti yang terjadi pada salah satu perkara yang melibatkan seorang nenek yang berasal dari kalangan bawah harus menjadi terpidana dan menjalani hukuman penjara selana 45 hari atas perbuatannya memetik buah kakao sebanyak 3 buah. Adapun perkara lain yang melobatkan seseorang yang memiliki kekuasaan terlibat perkara korupsi dengan jumlah besar mendapatkan hukuman selama enak bulan kurungan. Keduanya terpidana tersebut sama-sama menghadapi hukum dengan perkara yang berbeda yang dimana putusan tersebut mencerminkan adanya perilaku hukum yang hanya tajam terhadap masyarakat bawah dan justru terkesan memihak masyarakat golongan atas. Hal ini selanjutnya menjadi polemic dikalangan masyarakat yang menyoroti keadilan hukum (ICW, 2015)

Penindakan hukum yang tajam kebawah dan tumpul keatas, banyak menjadi sorotan di Indonesia, apalagi terkait kalangan orang-orang yang memiliki kekuasaan dan terlibat perkara hukum mendapatkan fasilitas dan dukungan bantuan hukum, sehingga dapat mempengaruhi besaran vonis yang dijatuhkan terhadapnya (Atmasasmita, 2016). Salah satu fenomena yang banyak memuat hal demikian yaitu kasus 
korupsi. Kasus korupsi yang saat ini banyak terjadi di kalangan elite termasuk pejabat cukup membuat masyarakat memandang lemahnya hukum di mata penguasa. Dimana jika dibandingkan dengan penerapan hukum di negara lain, menunjukkan perbedaan perlakuan hukum yang signifikan.

Di Indonesia perlakukan hukum terhadap kasus korupsi yang banyak terjadi mendapatkan hukum yang tidak sebanding dengan kerugian yang disebabkan. Sedangkan dinegara lain, perlakuan hukum pada perkara korupsi paling rendah adalah hukuman seumur hidup dan yang paling tinggi adalah ekseskusi mati (Atmasasmita, 2016). Kurangya taji perlakuan hukum pada kasus korupsi yang terjadi ditunjukan data KPK tahun 2013-2017 yang memuat 26 tersangka yang keseluruhan berasal dari kalangan pejabat yang mana terpidana tersebut tidak mendapatkan hukuman selayaknya.

Padahal hal ini telah dijelaskan dalam buku I KUHP yang memuat tentang sistem hukuman pidana pada pasal 10 yang meliputi hukuman mati, penjara, kurungan, dan hukuman denda yang termuat pada 3 keputusan (Prodjodikoro, 2016). Terkhusus pada kasus korupsi yang termuat pada pasal 18 pada ayat pertama butir d dalam UU No 31/1999 mengenai pemberantasan korupsi dengan sanksi pencabutan seluruh hak tertentu, dimana pencabutan hak tersebut didasarkan pada putusan yang diberikan majelis hakim. (Moeljatno, 2016). Pencabutan hak tertebtu yang dimaksud disini yaitu pencabutan hak asasi manusia pada kebebasan dipilih dan memilih dalam perspektif hukum (Tim Redaksi Nuansa Aulia., 2015).

Keterlaksanaan hukum yang sesuai dengan akibat yang dilakukan terpidana maksimal atau tidak terpengaruh pada aspek pelaksanan hukum tersebut atau dengan kata lain penegak hukumnya. Penegak hukum memiliki kewajiban untuk mengserasikan hubungan antara nilai dan kaidah yang diajabarkan secara detail dan di lakukan serta ditindaki sebagai implementasi penjabran nilai dan kaidah yang bertujuan menciptakan pertahanan dan mempertahankan agar kedamaian tetap terpelihara (Soekanto, 2018).

Hukum adalah bagian dari masyarakat yang ada dan diperadakan untuk masyarakat dan dilakukan didalam ruang lingkup masyarakat. Sehingga untuk mengasah taji hukum itu sendri, maka warga atua masyarakatlah yang menentukan ruang lingkup hukum tersebut berlaku sama. Adapun factorfaktor yang menjadi [engaruh penerapan hukum tersebut bertaji di masyarakat secara adil meliputi pada 5 faktor (Soekanto, 2018) yaitu:

a. Faktor hukumnya sendiri

b. Faktor penegak hukum, yakni pihak-pihak yang membentuk maupun menerapkan hukum

c. Faktor sarana atau fasilitas yang mendukung penegakan hukum

d. Faktor masyarakat yakni lingkungan di mana di mana hukum tersebut berlaku atau diterapkan

e. Faktor kebudayaan, yakni sebagai hasil karya, cipta dan rasa yang didasarkan pada karsa manusia di dalam pergaulan hidup.

Dalam kajian penerapan hukum terdapat dua teori yang dapat digunakan untuk mengoptimalkan penerapan hukum yang meliputi 1) teori absolut yang memuat pada pemberian hukuman terhadap pelaku guna memberikan kepuasan pada pihak korban. 2) teori relative yang memuat pada penjatuhan pidana dan melaksanakan hukum tersebut dengan berorientasi pada asa jera pelaku, dan 3) asas gabungan yang merupakan asas gabungan antara kedua teori sebelumnya yang memuat pada pemberian hukuman guna memberikan asa jera pada pelaku sekaligus memberikan jawaban atas akibat yang dirasakan korban sebagai suatu balasan kepada pelaku kejahatan (Ali, 2016).

Selanjutnya untuk hak politik pada pelaku korupsi akan dilakuakn pencabutan terhadap hak tersebut termasuk pada hak memilih dan hak dipilih yang dimuat pada pasal 18, dimana setiap individu memiliki hak kebabasan dalam berfikir, menggunakan hati Nurani, serta beragama. Sedangkan pada pasal 19 memuat tentanf kebebasan setiap warga untuk berpendapat, dan pasal 20-21 yang tergabung dalam Deklarasi Universal HAM (Moeljatno, 2016).

Penegakan hukum serta pemidanaan yang dilakukan bertujuan untuk mengatasi kejahatan secara rasional dengan memenuhi rasa keadilan untuk masyarakat yang menjadi akibat dari perbuatan seseorang, yang dimana perkara korupsi termasuk didalamnya dan termasuk pada kasus pidana (Alkostar, 2016).

\section{METODE}

Jenis penelitian ini adalah yuridis normatif dengan pendekatan perundang-undangan (statute approach) dan pendekatan kasus (case approach)(Soekanto, 2018). Adapun sumber data berdasarkan dua pendekatan tersebut adalah sumber data sekunder atau data kepustakaan dan dokumen yang berupa bahan-bahan hukum. Bahan-bahan hukum primer terdiri dari perundang-undangan, catatan-catatan resmi atau risalah dalam pembuatan undang-undang dan putusan-putusan hakim. Analisis data pada penelitian hukum yuridis normatif ini secara deskriptif kualitatif.

\section{HASIL DAN PEMBAHASAN}

\subsection{Siapa saja Terdakwa yang dapat Dijatuhi Pidana Tambahan Berupa Pencabutan Hak-Hak Politik Tertentu Dalam Kasus Korupsi}

Usaha memberantas tindak pidana korupsi dapat dilakukan dengan mempertajam sudut pandang penegak hukum yang selanjutnya memberikan ketajanaman penegak hukum dalam memutuskan siapa saja yang seharusnya mendapatkan pidana tambahan dalam tindak pidana kasus korupsi berupa pencabutan hak tertentu dalam aspek politik. Dalam penegakan hukum terhadap kasus korupsi, berperan tidak hanya pada pemberian hukuman sebagai asa jera namun juga pada melaksanakan amanat liberasi (nahi munkar) serta transendensi (tu'minuuna billah) dalam menunaikan kewajibanna asebagai pengak hukum. Adapun yang orangorang yang seharusnya mendapatkan pidana tambahan dalam tindak pidana kasus korupsi berupa pencabutan hak tertentu dalam aspek politik meliputi pada 3 ketentuan yaitu:

a. Mereka yang melakukan korupsi dan berada dalam jabatan pengurus inti dalam sebuah partai politik seperti ketua umu, sekretaris, dan bendahara, serta pengurus bidang-bidang kerja dalam partai politik.

b. Mereka yang mengkorupsi anggaran negara guna membangun infrastruktur dan kesjahteraan masyarakat banyak.

c. Mereka yang terus melakukan tindak korupsi secara berulang.

Penjatuhan hukum tambahan tersebut meliputi pada pencabutan hak memilih dan dipilih selama kurun waktu yang ditentukan berdasarkan pada penetapan putusan hakim. Aturan tersebut selanjutnya termuat [ada putusan MK no 1417/PUU-V/2007 yang memuat pengujian pada pasal 58 bagian f dalam UU no 328/2004 yang mana menjelaskan bahwa 
pemrintah daerah terhadap UUD 1945 yang mengatur dengan jelas tentang hak pencabutan hak pilih (Moeljatno, 2016).

\subsection{Dalam Hal apakah Terdakwa Tindak Pidana Korupsi Dijatuhi Pidana Tambahan Berupa Pencabutan Hak Politik Tertentu}

Kriteria penjatuhan putusan pidana tambahan yang meliputi pada pencabutan hak pilih aktif dan pasif termuat pada putusan MK no 14- 17/PUU-V/2007 yang memuat pengujian pada pasal 58 bagian $\mathrm{f}$ dalam UU no 328/2004 yang mana menjelaskan bahwa pemerintah daerah terhadap UUD 1945 yang mengatur dengan jelas tentang hak pencabutan hak pilih. Adapun perihal yang membuat terpidana mendapatkan pidana tambahan berdasarkan pada analisis beberapa kasus korupsi yaitu:

a. Terdakwa yang merupakan anggota DPR RI yang bertempat di bagian Komisi tujuh, di mana sebagai anggota DPR RI, terdakwa tidak seharusnya melakukan korupsi karena terdakwa sebagai Panutan atau contoh yang baik untuk masyarakat;

b. Terdakwa yang merupakan anggota DPR RI, memberikan contoh perbuatan korupsi yang mencoreng nama baik Lembaga DPR RI

c. Terdakwa yang dengan sengaja tidak mengakui perbuatannya sehingga dengan kata lain terdakwa tidak menunjukkan penyesalan terhadap korupsi yang dilakukan

d. Terdakwa yang merupakan anggota DPR RI termasuk dalam Jabatan Politis,

Sehingga berdasarkan pada pertimbangan sudah sepantasnya dijatuhi Pidana Tambahan berupa Pencabutan Hak Memilih dan Dipilih dalam Pemilihan Jabatan Publik / Jabatan Politis

Berdasarkan pada hasil penelitian, diperoleh bahwa terdakwa yang dapat Dijatuhi Pidana Tambahan Berupa Pencabutan Hak-Hak Politik Tertentu Dalam Kasus Korupsi memuat 4 kriteria yaitu

a. Terdakwa yang merupakan anggota DPR RI yang bertempat di bagian Komisi tujuh, di mana sebagai anggota DPR RI, terdakwa tidak seharusnya melakukan korupsi karena terdakwa sebagai Panutan atau contoh yang baik untuk masyarakat;

b. Terdakwa yang merupakan anggota DPR RI, memberikan contoh perbuatan korupsi yang mencoreng nama baik Lembaga DPR RI

c. Terdakwa yang dengan sengajatidak mengakui perbuatannya sehingga dengan atalain terdakwa tidak menunjukkan penyesalah terhadap korupsi yang dilakukan

d. Terdakwa yang merupakan anggota DPR RI termasuk dalam Jabatan Politis,

Berdasar pada hasil analisis diperoleh bahwa pertimbangan Majelis Hakim Tingkat Banding sejalan dengan pendapat guru besar Fakultas Hukum Universitas Bosowa Makassar Marwan Mas Reformasi hukum adalah salah satu unsur yang penting dalam melakukan pemberantasan korupsi dalam mengembalikan kepercayaan public baik ruang lingkup dalam negeri maupun internasional, terkhusus pada supremasi hukum dan Lembaga yang dalam ruang lingkup sebagai penegak hukum.
Permasalahan yang saat ini bermunculan Ketika pembicaraan terkait hukum dan penegak hukum dimulai, maka akan Nampak komentar dan tanggapan yang cukup mengejek dan mencibir akan penindakan hukum yang dilakukan saat ini. Fenomena Tindakan yang hukum yang dianggap cepat tanggap dalam kurun beberapa waktu terlihat pada Lembaga kepolisian yang mendapat tanggapan baik dari $\mathrm{m}$ masyarakat dalam mengungkapkan jaringan terorisme dan Lembaga komisi pengendalian korupsi yang menjerat menteri pada periode Presiden SBY dalam tubuh Kabinet Indonesia Bersatu jilid Kedua tahun 2004-2014. Penindakan dalam penegakan hukum ini sudah seharusnya tidak melihat status dan kedudukan harus menjadi pedoman Lembaga Kepolisian beserta Kejaksaan dalam pemberantasan korupsi”.

Tujuan penjatuhan hukuman Terpidana Korupsi baik itu pidana pokok dan pidana tambahan keduanya sudah jelas berbeda yakni (Prodjodikoro, 2016) :

1. Pidana pokok berupa kurungan bertujuan untuk memberikan asas jera kepada terpidana agar merasakan hukuman atas tindak kejahatan yang telah dilakukan

2. Pidana tambahan berupa pencabutan hak dalam politik bertujuan untuk tidak memberikan peluang kepada terpidana mendapatkan jabatan setelah masa hukuman selesai sebagai efek jera telah melakukan perbuatan yang merugikan negara

Tujuan pemberian pidana tambahan berupa tindak pidana pada pencabutan hak pilih dalam berpolitik yang merupakan langkah jitu dalam memberantas tindak korupsi oleh apparat yang merupakan pejawab negara, yang sudah sepatutnya mendapatkan dukungan dan apresiasi dari masyarakat. Meskipun dalam proses penerapan pidana tambahan ini mendapatkan sorotan dari berbagai pihak, namun hal tersebut tidak harus menjadi peertimbangan majelis hakim dalam memberikan putusan agar penetapan hukuman pada terpidana korupsi mendapatkan vonis yang benar-benar sesuai dengan perbuatannya yang merugikan negara.

Selain itu, kita sebagai penegak hukum sudah sepatutnya ikut menyadari akan sisi lemahnya regulasi dalam penerapan hukum tersebut, sehingga rentang kehilangan kepercayaan dari masyarakat. Oleh sebab itu penegak hukum membutuhkan instrument hukum tambahan dalam menjalankan mekanisme hukum terkait pada pemberian pidana tambahan berupa pencabutan hak politik agar senantiasa sejalan dengan cita-cita bersama, dalam mewujudkan hukum yang tegas dalam adil dalam melakukan pemberantasan Korupsi (Waluyo, 2017).

Pencabutan hak politik sebetulnya bisa menjadi instrumen baru bagi penegak hukum dalam memberikan hukuman berupa efek jera terhadap terpidana korupsi. Harus diakui, penjatuhan pidana selama ini dinilai tidak efektif mengurangi pelaku korupsi, khususnya yang menduduki jabatan publik. Pidana badan (penjara) ataupun denda/uang pengganti tidak sepenuhnya mencerminkan kerugian yang ditimbulkan pelaku korupsi. Dari sisi pelaku, adakalanya pemidanaan itu dinilai setimpal karena yang bersangkutan mendapatkan keuntungan tertentu yang tidak mampu disentuh penegak hukum sehingga ketika selesai menjalani pidana, keuntungan tersebut masih bisa dinikmati pelaku.

Ada tiga hal yang harus diperhatikan didalam 
pencabutan hak politik itu.

1. Subjek Pelaku Tindak Pidana.

Ada yang mengemukakan pandangannya bahwa pencabutan hak politik lebih relevan jika diberikan kepada pelaku yang menduduki jabatan publik dari hasil pemilihan umum (pemilu). Jabatan yang digunakan pelaku untuk melakukan tindak pidana korupsi berkorelasi dengan hak politik yang dicabut tersebut sehingga hal ini dimaksudkan agar pelaku tidak lagi menduduki jabatan yang sama, sebab telah terbukti menyalahgunakan kekuasaannya.

Apabila menggunakan perspektif yang lebih luas, pencabutan hak politik seharusnya dapat dijatuhkan terhadap seluruh pejabat publik yang terbukti melakukan kejahatan korupsi. Perluasan semacam ini sebetulnya sudah pernah dilakukan terhadap posisi jabatan publik yang tidak dipilih melalui pemilu, misalnya dalam kasus korupsi yang melibatkan bekas Kepala Korlantas Polri Djoko Susilo (DS). Perpektif terakhir ialah seluruh pelaku tindak pidana korupsi dapat dijatuhi sanksi pencabutan hak politik. Seseorang yang telah terbukti di pengadilan melakukan kejahatan korupsi sudah pasti memiliki pengalaman untuk menyalahgunakan jabatan baik sebagai pejabat publik atau sebagai pihak ketiga yang memengaruhi pejabat publik untuk menyalahgunakan jabat-annya. Misalnya terhadap pelaku korupsi dari pihak swasta yang menyuap pejabat publik sudah tentu memiliki potensi lebih besar untuk menyalahgunakan jabatannya ketika menduduki jabatan publik.

2. Pembatasan Waktu Pencabutan Hak Politik.

Dalam beberapa putusan yang telah ada, pencabutan hak politik masih bervariasi baik tanpa dibatasi waktu ataupun dibatasi dalam waktu tertentu. Idealnya pencabutan hak politik memang dilakukan tanpa batas waktu, sebab ini akan menjadi pembelajaran dan penjeraan baik bagi pelaku maupun masyarakat secara umum. Bahkan perlu ada perluasan terhadap jabatan yang tidak boleh diberikan kepada bekas terpidana korupsi, yaitu seluruh jabatan yang memperoleh dana dari negara ataupun dari perusahaan negara (BUMN/BUMD). Pelaku korupsi juga tidak akan diperbolehkan menduduki jabatan strategis di partai politik, sebab mendapatkan bantuan keuangan dari negara secara periodik. Penegasan ini diperlukan agar di kemudian hari para pelaku korupsi sekalipun tidak menduduki jabatan publik tetapi mampu mengendalikan partai politik yang notabene memiliki kekuasaan yang besar. Di lain pihak, jika pencabutan hak politik dilakukan berbatas waktu, pembatasannya perlu mempertimbangkan masa pemilu/pemilukada, bukan dibatasi berdasarkan hitungan tahun secara linier. Misalnya pelaku tindak pidana korupsi dicabut hak politik selama tiga periode pemilu/pilkada, bukan justru dicabut hak politik selama tiga tahun.

3. Memiliki Dasar Hukum Yang Kuat

Perlu ada pedoman bagi penegak hukum untuk memaksimalkan penggunaan pidana pencabutan hak politik dalam kasus korupsi. Minimal di setiap instansi penegak hukum atau minimal arahan tentang urgensi pidana pencabutan hak politik. Termasuk bagi para hakim tipikor, perlu ada penguatan tentang pemahaman pemidanaan khusus bagi pelaku korupsi. Hal itu bisa dimulai dari proses seleksi hakim hingga pelatihan periodik bagi hakim tipikor mengenai perkembangan pemidanaan yang perlu diterapkan bagi pelaku tindak pidana korupsi, salah satunya tentang urgensi pencabutan hak politik.

Adapun hak yang dapat dilakuan pencabutan berdasarkan pada Pasal 35 Ayat (1) KUHP, antara lain:

1) Hak menduduki jabatan

2) Hak bergabung dalam $\mathrm{TN}$

3) Hak kebebasan dipilih dan memilih

4) Hak sebagai wali, pengawas baik untuk orang lain maupun yang tergolong keluarga

5) Hak dalam mengelola kekuasaan sebagai wakil baik untuk orang lain maupun yang tergolong keluarg dan

6) Hak mengelola sebuah pekerjaan

Hukuman tambahan di masa lalu dapat merupakan kematian perdata (mort civile) bagi terpidana pada perkara kejahatan kelas kakap, akan tetapi saat ini hukuman tambahan tersebut tidak lagi digunakan. Hukuman tambahan diterapkan bertujuan agar dapat melakukan pencegahan terhadap seseorang yang memiliki niat untuk melakukan penyalahgunaan jabatan dan wewenang yang dipegang.

Perbuatan yang dilakukan oleh salah seorang anggota DPR RI (Hj. Dewi Aryaniliza alias Dewi Yasin Limpo) yang melakukan Tindakan transaksional dengan menyalahgunakan kekuasaan elektoral untuk kepentingan pribadi telah merusak kepercayaan rakyat terkhususnya pada masyarakat yang telah mimilihya untuk melaju ke DPR RI.

Perilaku Hj. Dewi Aryaniliza alias Dewi Yasin Limpo menjadi ironi demokrasi karena menggunakan jabatannya untuk mendapatkan dana suap dari pengusaha sehingga mencoreng citra wakil rakyat dan kepercayaan rakyat berskala nasional. Hubungan transaksional antara Hj. Dewi Aryaniliza alias Dewi Yasin Limpo sebagai Anggota Legislatif dengan Setiady Jusuf merupakan Korupsi politik, karena dilakukan Hj. Dewi Aryaniliza alias Dewi Yasin Limpo dalam melakukan tindak orupsi berada pada posisi sebagai wakil rakyat adalahkejahatan yang serius.

Dalil yang menjadi pertimbangan Majelis hakim dalam menetapkan vonis terkait pada pidana tambahan yaitu dengan pencabutan hak politik antara lain:

1. Terdakwa yang merupakan anggota DPR RI yang bertempat di bagian Komisi tujuh, di mana sebagai anggota DPR RI, terdakwa tidak seharusnya melakukan korupsi karena terdakwa sebagai Panutan atau contoh yang baik untuk masyarakat;

2. Terdakwa yang merupakan anggota DPR RI, memberikan contoh perbuatan korupsi yang mencoreng nama baik Lembaga DPR RI

3. Terdakwa yang dengan sengajatidak mengakui perbuatannya sehingga dengan atalain terdakwa tidak menunjukkan penyesalah terhadap korupsi yang dilakukan

4. Terdakwa yang merupakan anggota DPR RI termasuk dalam Jabatan Politis,

Pada kasus korupsi Dewi Yasin Limpo, majelis hakim kasasi MA dalam menetapkan putusan dengan mengurangi masa pencabutan hak politik selama 12 tahun mendapat pengurangan 7 tahun sehingga hanya berlaku selama 5 tahun. Mencermati vonis tersebut tentunya menimbulkan pertanyaan, terkait adanya perbedaan penetapan vonis antara hakim satu dan hakim lain, sedangkan aturan yang digunakan adalah aturan yang sama.

Berdasar pada kejadian tersebut, saat MA telah berupaya merumuskan terkait peraturan internalnya agar putusan hakim 
atau vonis serupa terkait pencabutan hak agar senantiasa berjalan selaras yang tertuang dalam PERMA MA Agung No 1/2020 yang memuat Pedoman Pemidanaan Pasal 2 dan Pasal 3 Undang-undang Tindak Pidana Korupsi yang baru-baru ini di terapkan dan disosialisasikan untuk menghindari adanya Disparitas Putusan (Hestu Cipto Handoyo, 2016).

Adapun hal yang termasuk perihal penting dalam menindaki perkara korupsi adalah kesolidan dari aparat negara dan masyarakat dalam melawan dan memberantas korupsi. Apau Tindakan yang diambil dan ditetapkan jika dalam pengaplikasian putusan tidak tegas dan konsisten dalam mengungkap perkara korupsi, maka pemberantasan korupsi tidak akan maksimal. Apalagi saat ini tidak sedikit jaksa yang senantiasa ragu dalam menuntut tindak pidana korupsi sebab melibatkan orang-orang yang memiliki otoritas besar, maka dalam hal ini dibutuhkan keberanian dari jaksa agar secara bersama-sama meningkatkan kesadaran masyarakat akan hukum dan keberanian jaksa untuk bertindak sebagai penegak hukum.

\section{KESIMPULAN DAN SARAN}

Hasil penelitian dan pembahasan dapat disimpulkan bahwa penjatuhan putusan pidana tambahan berupa pencabutan hak memilih dan dipilih dalam jabatan publik kepada terpidana korupsi merupakan upaya yang menjerakan serta upaya preventif dalam pencegahan terjadinya tindak pidana korupsi sehingga Hakim harus selalu konsisten dalam menjatuhkan pidana tambahan pencabutan hak politik terhadap mereka yang menyalahgunakan kewenangan atau kekuasaan jabatan atau posisi politik dan Seharusnya di dalam menjatuhkan pidana tambahan pencabutan hak politik, majelis hakim harus mencantumkan kapan mulai berlakunya serta batas waktu berlakunya agar tidak terjadi kematian perdata bagi Terpidana setelah ia menjalani hukuman pokoknya

\section{DAFTAR PUSTAKA}

Ali, M. (2016). Asas, Teori \& Praktek Hukum Pidana Korupsi (Ketujuh). UII Press.

Alkostar, A. (2016). Korupsi Politik di Negara Modern (Kelima). FH UII Press.

Atmasasmita, R. (2016). Sekitar Masalah Korupsi: Aspek Nasional dan Aspek Internasional. (Ketujuh). MAndar Maju.

Hestu Cipto Handoyo, B. (2016). Hukum Tata Negara, Kewarganegaraan \& Hak Asasi Manusia. Memahami Proses Konsolidasi Sistem Demokrasi di Indonesia (Kesepuluh). Andi Offset.

ICW. (2015). Koruptor Dihukum Ringan. http://www.republika.co.id/berita/koran/publik/14/09/03 /nbbcs77-icw-747

Marwan Mas (2014) Pemberantasan Tindak Pidana Korupsi (Pertama) Ghalia Indonesia

Moeljatno. (2016). KUHP : Kitab Undang-Undang Hukum Pidana (Kedua Pulu). Bumi Aksara.

Prodjodikoro, W. (2016). Asas-Asas Hukum Pidana di Indonesia (Kelima). Refika Aditama.

Soekanto, S. dan S. M. (2018). Penelitian Hukum Normatif
(Kelima bel). Raja Grafindo Persada.

Tim Redaksi Nuansa Aulia. (2015). Undang-Undang Tindak Pidana Korupsi \& Suap Disertai Undang-Undang Tentang Pencucian Uang (Kelima).

Waluyo, B. (2017). Pidana dan Pemidanaan (Keduabelas). Sinar Grafika. 